INOBIS: Jurnal Inovasi Bisnis dan Manajemen Indonesia

Volume 03, Nomor 04, September 2020

Matdio Siahaan, Ahmad Torikul Muhidin

\title{
Evaluasi Sistem Pengendalian Internal Persediaan Barang Jadi Pada PT. Denso Manufacturing Indonesia
}

\author{
Matdio Siahaan \\ Universitas Bhayangkara Jakarta Raya \\ Ahmad Torikul Muhidin \\ Universitas Bhayangkara Jakarta Raya \\ matdio.siahaan@dsn.ubharjaya.ac.id \\ torikulmuhidin@gmail.com
}

\begin{abstract}
Abstrak
Penelitian ini bertujuan untuk mengetahui bagaimana sistem pengendalian internal persediaan barang jadi yang diterapkan PT. Denso Manufacturing Indonesia Tahun 2018. Data yang digunakan dalam penelitian ini dengan menggunakan COSO. Berdasarkan metode deskriptif kualitatif, metode pengambilan sampel dan populasi dalam penelitian ini yaitu terdiri dari 15 karyawan departement logistik dan 5 karyawan departemen produksi. Hasil penelitian menunjukkan bahwa PT. Denso Manufacturing Indonesia memiliki sistem pengendalian internal persediaan barang jadi yang baik dan efektif namun masih terdapat beberapa kendala dan hambatan dalam pelaksanaan pengendalian internal yang sudah ada, dan tidak ditemukan adanya penyimpangan hanya terdapat beberapa kekurangan pada pengendalian internal persediaan barang jadi yang sudah dijalankan saat ini.
\end{abstract}

\section{Kata Kunci : Analisis, Pengendalian Internal COSO, Persediaan Barang Jadi}

\section{Pendahuluan}

Perkembangan ekonomi diindonesia berkembang dengan pesat sehingga pengusaha dituntut bekerja dengan lebih efisien dalam menghadapi persaingan yanglebih ketat demi menjaga kelangsungan operasional perusahaan. Kelangsungan proses produksi didalam suatu perusahaan akan dipengaruhi oleh berbagai faktor yaitu modal, teknologi, persediaan bahan baku, persediaanbahan jadi dan tenaga kerja. persediaan (inventory) sebagai elemen modal kerja merupakan aktiva yang selalu berputar.Bagi banyak perusahaan, penjualan merupakan sumber penghasilan yang utama dan merupakan komponen terbesar dalam penentuan laba kotor.

Persediaan merupakan unsur yang paling aktif dalam perusahaan dagang dan salah satu syarat pokok yang harus dipenuhi serta dimiliki oleh suatu perusahaan didalam aktifitas perdagangan karena dalam perdagangan yang diperdagangkan adalah persediaan tersebut. Persediaan merupakan hal sangat yang penting bagi setiap perusahaan karena persediaan merupakan sumber utama pendapatan dalam merealisasi laba perusahaan. persediaan adalah suatu barang-barang yang masih dalam pekerjaan proses produksi atau aktiva meliputi barang milik perusahaan dengan maksud untuk dijual dalam satu periode usaha normal ataupun persediaan bahan baku yang menunggu penggunaanya dalam suatu proses produksi

PT. Denso Manufacturing Indonesia adalah perusahaan manufactur yang sangat membutuhkan persediaan di setiap proses produksinya. Adanya pengendalian internal yang baik dan teratur dalam mengelola persediaan, maka pimpinan perusahaan akan memperoleh laporan-laporan yang bermanfaat untuk meningkatkan efektivitas perusahaan, juga membantu dalam mengambil kebijakan keputusan maupun pertanggungjawaban dalam memimpin 
perusahaan. pengendalian intrnal atas persediaan diharapkan dapat menciptakan aktivitas pengendalian terhadap perusahaan yang efektif dalam menentukan jumlah persediaan optimal yang dimiliki perusahaan. mencegah berbagai tindakan pelanggaran dan penyelewangan yang dapat merugikan perusahaan, pelanggaran terhadap kebijakan yang diterapkan atas persediaan, serta memberikan pengamanan fisik terhadap persediaan dari pencurian dan kerusakan.

\section{Landasan Teori}

\section{Pengendalian Internal}

Menurut Hery (2015,h 158) Pengendalian internal adalah seperangkat kebijakan dan prosedur untuk melindungi aset atau kekayaan perusahaan dari segala bentuk tindak penyalahgunaan, menjamin tersedianya informasi akuntansi perusahaan yang akurat, dan memastikan bahwa semua ketentuan ataupun peraturan hukum undang- undang serta kebijakan manajemen telah dipatuhiatau dijalankan sebagaimana mestinya oleh seluruh karyawan perusahaan.

\section{Kegiatan Pengendalian Internal}

Menurut Sujarweni (2015, h 74) kegiatan pengendalian internal adalah suatu tindakan yang dibutuhkan untuk mengatasi risiko. Pada kegiatan ini antara lain menetapkan pelaksanaan prosedur kebijakan yang sudah dibuat serta memastikan tindakan untuk mengatasi risiko sudah dipatuhi dan dilaksanan secara efektif dan efisien. Beberapa kegiatan pengendalian internal yang dilakukan adalah sebagi berikut :

1. Pemberian Otorisasi atas Transaksi dan Kegiatan.

2. Pembagian Tugas dan Tanggung Jawab.

3. Merancang Dokumen yang akan digunakan.

4. Perlindungan yang cukup ketat terhadap Kekayaan dan Catatan Perusahaan.

5. Pemeriksaan Terhadap Kinerja Perusahaan.

\section{Komponen Pengendalian Internal (COSO)}

Menurut Hery (2017, h 134) kerangka kerja pengendalian internal yang digunakan oleh sebagian besar perusahaan A.S dikeluarkan oleh Committee of Sponsoring Organizations (COSO). Komponen pengendalian internal COSO meliputi : lingkungan pengendalian, penilaian risiko, aktivitas pengendalian, informasi dan komunikasi akuntansi serta pemantauan.

\section{Lingkungan Pengendalian}

Tanpa lingkungan pengendalian yang efektif, keempat komponen lainnya mungkin tidak akan menghasilkan pengendalian internal yang efektif. Lingkungan pengendalian berfungsi sebagai payung bagi keempat komponen pengendalian internal lainnya.

Lingkungan pengendalian terdiri atas tindakan, kebijakan, dan prosedur yang mencerminkan sikap manajemen puncak, para direktur, dan pemilik entitas secara keseluruhan mengenai pengendalian internal serta arti pentingnya bagi entitas tersebut. Auditor perlu mempertimbangkan sub komponen dari lingkungan pengendalian itu sendiri, yaitu sebagai 
berikut :

1) Integritas dan Nilai-Nilai Etis

2) Komitmen pada Kompetensi

3) Partisipasi Dewan Komisaris dan Komite Audit

4) Filosofi dan Gaya Operasi Manajemen

5) Struktur Organisasi

6) Kebijakan perihal Sumber Daya Manusia (Karyawan Entitas)

\section{Penilaian Risiko}

Merupakan tindakan yang dilakukan oleh manajemen untuk mengidentifikasi dan menganalisis risiko-risiko terkait penyusunan laporan keuangan yang sesuai dengan standar akuntansi. Penilaian risiko oleh manajemen berbeda dengan penilaian risiko oleh auditor, walaupun ada keterkaitannya. Apabila manajemen menilai risiko sebagai bagian dari perancangan dan pelaksanaan pengendalian internal untuk memperkecil kekeliruan serta kecurangan, sedangkan auditor menilai risiko untuk memutuskan jenis dan cakupan bukti yang dibutuhkan dalam pemeriksaan. Jika manajemen secara efektif menilai dan menanggapi risiko tersebut, biasanya auditor akan mengumpulkan lebih sedikit bukti audit dari pada jika manajemen gagal dalam mengidentifikasi atau menindaklanjuti risiko yang signifikan.

\section{Aktivitas Pengendalian}

Hal ini merupakan kebijakan dan prosedur untuk membantu memastikan bahwa tindakan yang diperlukan untuk mengatasi risiko telah diambil guna mencapai tujuan entitas. Kebijakan dan prosedur tersebut terdiri atas :

1) Pemisahan Tugas

2) Otorisasi yang Tepat atas Transaksi

3) Dokumen dan Catatan yang Memadai

4) Pengendalian Fisik atas Aset dan Catatan

5) Pemeriksaan Independen atau Verifikasi Internal

\section{Informasi dan Komunikasi Akuntansi Tujuan dari sistem informasi dan}

komunikasi Akuntansi adalah agar transaksi yang dicatat, diproses, dan dilaporkan telah memenuhi keenam tujuan audit umum atas transaksi, yaitu :

1) Transaksi yang dicatat memang ada

2) Transaksi yang ada sudah dicatat

3) Transaksi yang dicatat dinyatakan dalam jumlah yang benar

4) Transaksi yang dicatat diposting dan diikhtisarkan dengan benar

5) Transaksi diklasifikasi dengan benar

6) Transaksi dicatat pada tanggal yang benar

\section{Pemantauan}

Aktivitas pemantauan berhubungan dengan penilaian atas mutu pengendalian internal secara berkesinambungan oleh manajemen untuk menentukan bahwa pengendalian telah berjalan sebagaimana yang diharapkan.dan dimodifikasi sesuai dengan perkembangan kondisi 
yang ada dalam perusahaan. Informasi yang dinilai berasal dari berbagai sumber, termasuk studi atas pengendalian internal yang ada, laporan auditor internal, umpan balik dari personil operasional, dan lainnya.

\section{Menilai Risiko Pengendalian}

Menurut Hery (2017, h 148) Ada dua hal penting menentukan dapat tidaknya entitas diaudit, yaitu integritas manajemen dan memadainya catatan akuntansi. Jika manajemen tidak memiliki integritas, sebaiknya auditor tidak menerima penugasan audit.

Berikut adalah langkah-langkah dalam menilai risiko pengendalian :

1. Mengidentifikasi tujuan audit.

2. Mengidentifikasi pengendalian yang ada.

3. Menghubungkan pengendalian dengan tujuan audit terkait.

4. Mengidentifikasi dan Mengevaluasi Defisiensi Pengendalian, Difisiensi yang Signifikan dan Kelemahan yang Material.

5. Menghubungkan Kelemahan yang Material dan Defisiensi yang Signifikan dengan Tujuan udit Terkait.

6. Menilai Risiko Pengendalian untuk Setiap Tujuan Audit yang Terkait.

\section{Keterbatasan Pengendalian Internal}

Faktor manusia merupakan faktor yang sangat penting dalam setiap pelaksanaan sistem pengendalian internal. Suatu sistem pengendalian yang baik akan dapat menjadi tidak efektif karena adanya karyawan yang kelelahan, ceroboh, atau bersikap acuh tak acuh. Demikian juga halnya dengan kolusi, dimana kolusi ini akan dapat secara signifikan mengurangi keefektifan suatu sistem dan mengeleminasi proteksi yang ditawarkan dari pemisahan tugas. Belum lagi adanya suatu pandangan umum yang mengatakan bahwa pada prinsipnya didunia ini tidak ada sesuatu yang sempurna, termasuk sistem pengendalian internal yang dijalankan perusahaan.

\section{Pengertian Persediaan}

Menurut Mulyadi (2014, h 99) yang dimaksud persediaan adalah barang-barang yang dibeli perusahaan dengan maksud untuk dijual lagi (barang dagangan), atau masih dalam proses produksi yang akan diolah lebih lanjut menjadi barang jadi kemudian dijual (barang dalam proses) atau akan dipergunakan dalam proses produksi barang yang kemudian dijual.

\section{Jenis-Jenis Persediaan}

Jenis pesediaan menurut Heizer dan Render (2015, h 554) sebagai berikut:

1. Persediaan bahan mentah (raw material inventory) Telah dibeli, tetapi belum diproses. Persediaan ini dapat digunakan untuk memisahkan (yaitu, menyaring) pemasok dari proses produksi.

2. Persediaan barang dalam proses (work- in-process-WIP inventory) Komponenkomponen atau bahan mentah yang telah melewati beberapa proses perubahan, tetapi belum selesai.

3. MRO (maintenance/repair/operating) Persediaan yang disediakan untuk perlengkapan pemeliharaan operasi (maintenance/repair/operating-MRO) yang dibutuhkan untuk menjaga agar mesin dan proses tetap produktif. 
4. Persediaan barang jadi (finish-good inventory)

Produk yang telah selesai dan tinggal menunggu pengiriman. Barang jadi dapat dimasukkan ke persediaan karena permintaan pelanggan pada masa mendatang tidak diketahui.

\section{Fungsi - Fungsi Persediaan}

Dilihat dari fungsinya, menurut Heizer \& Render (2015, h 553). Persediaan dapat memiliki berbagai fungsi yang menambah fleksibilitas operasi perusahaan. Keempat fungsi persediaan adalah sebagai berikut:

1. Untuk memberikan pilihan barang agar dapat memenuhi permintaan.

2. Untuk memisahkan beberapa tahapan dari proses produksi.

3. Untuk mengambil keuntungan dari potongan jumlah karena pembelian dalam jumlah besar dapat menurunkan biaya pengiriman barang.

4. Untuk menghindari inflasi dan kenaikan harga. Persediaan dapat memiliki berbagai fungsi yang menambah fleksibilitas operasi perusahaan.

\section{Manfaat Persediaan}

Menurut Eddy Herjanto (2010: 238), beberapa manfaat persediaan dalam memenuhi kebutuhan perusahaan, sebagai berikut :

a. Menghilangkan resiko keterlambatan pengiriman bahan baku atau barang yang dibutuhkan perusahaan.

b. Menghilangkan resiko jika material yang dipesan tidak baik sehingga harus dikembalikan.

c. Menghilangkan resiko terhadap kenaikan harga barang atau inflasi.

d. Untuk menyimpan bahan baku yang dihasilkan secara musiman sehingga perusahaan tidak akan kesulitan jika bahan itu tidak tersedia di pasaran.

e. Mendapatkan keuntungan dari pembelian berdasarkan diskon kuantitas.

f. Memberikan pelayanan kepada pelanggan dengan tersedianya barang yang diperlukan.

\section{Metode Penelitian}

\section{Persediaan Barang Jadi}

\section{Prosedur Pengelolaan Persediaan Barang Jadi}

Berikut ini adalah beberapa prosedur penanganan persediaan dengan menggunakan just in time. Prosedur pengelolaan persediaan barang jadi sebagai berikut :

1. Prosedur pengiriman persediaandimulai pada saat adanya permintaan atau order dari Costumer yang berisi jenis, ukuran, warna, dan jumlah barang yang diminta serta waktu pengiriman yang diminta oleh Costumer.

2. Setelah order atau pemesanan yang dilakukan oleh costumer maka tahap selanjutnya adalah penanganan order yang dilakukan oleh bagian Administration. Dalam tahap ini administration membuat Costumer Order Lists yang kemudian didistribusikan ke bagian gudang. 
3. Setelah dibuat Costumer Order Lists maka bagian gudang akan menganalisa dan mendata Costumer Order List tersebut, sebagai dasar pembuatan Permintaan Pembeliaan Barang yang kemudian diserahkan ke bagian Administration.

4. Bagian Administration akan membuat Purchasing Order sesuai dengan data yang telah diberikan oleh bagian gudang yang kemudian diberikan kepada kepala cabang untuk disetujui. Dan bila telah disetujui maka Purchasing Order tersebut akan dikirimkan ke bagian gudang di kantor pusat.

5. Bagian gudang di kantor pusat akan mengirimkan barang yang diminta ke bagian gudang di kantor cabang Bogor sesuai dengan Purchasing Order yang telah diberikan oleh bagian Administration.

6. Bagian gudang akan membuat Laporan Barang Masuk sesuai dengan Surat Jalan Barang yang diberikan oleh bagian pengiriman dari kantor pusat serta akan menyimpan dan menahannya sampai batas pengiriman.

7. Bila batas waktu pengiriman barang telah cukup maka barang akan dikirim oleh bagian Gudang kepada Costumer dengan menggunakan Surat Jalan.

\section{Metode pencatatan persediaan}

Menurut Hery (2016: 70) seorang akuntan harus hati-hati terutama pada pencatatan dan penilaian atas persediaaan.

Untuk mencatat transaksi-transaksi yang mempengaruhi nilai persediaan, terdapat dua metode sebagai berikut:

\section{Metode Fisik/Periodi(Periodic/Phisical Inventory Sistem)}

Dalam metode melalui ayat jurnal penyesuaian pencatatan persediaan hanya dilakukan pada akhir periode akuntansi.

2. Metode Perpetual (Continual Inventory Sistem)

Setiap terjadi transaksi yang mempengaruhi persediaan pencatatan persediaan dilakukan dalam metode ini.

\section{Metode Penilaian Persediaan}

Menurut kartikahadi (2012: 298) ada beberapa metode penilaian persediaan, yaitu :

1. Identifikasi khusus

Metode ini lazimnya digunakan untuk pedagangan atau perusahaan dagang yang khusus atau unik dan lazimnya bernilai tinggi, misalnya barang antik, gaun pengantin yang dirancang khusus, bangunan rumah dan lain-lain.

2. Rata-rata (Average)

Dalam metode ini rata-rata tertimbang (weighted average) biaya barang yang tersedia untuk dijual (persediaan awal dan pembelian) dibagi dengan unit tersedia untuk dijual, untuk mendapatkan biaya rata-rata per-unit.

3. Masuk Pertama Keluar Pertama (First In Firts Out/ FIFO)

Metode ini mengasumsikan bahwa barang yang pertama dibeli merupakan barang yang pertama dijual. Keunggulan metode ini terletak pada nilaipersediaan yang dilaporkan pada laporan keuangan.

4. Masuk Terakhir Keluar Pertama (Last In First Out/ LIFO)

Metode ini mengasumsikan bahwa barang yang terakhir dibeli merupakan barang yang pertama dijual. 


\section{Siklus Persediaan}

1. Memproses pesanan pembeliaan.

2. Menerima bahan baku.

3. Menyimpan bahan baku.

4. Memproses barang jadi.

5. Menyimpan barang jadi.

6. Mengirimkan barang jadi.

\section{Metode Penelitian}

\section{Lokasi Penelitian}

Penelitian ini dilakukan di PT. Denso Manufacturing Indonesia yang beralamat di Kawasan Industri MM2100 Blok FF-3, 5, 6 Danau Indah, Cikarang Barat. Bekasi, Jawa Barat 17530 - Indonesia.

\section{Metode Pengumpulan Data}

Dalam penelitian ini penulis akan menggunakan data primer dan data sekunder. Data primer yang akan digunakan berupa hasil kuesioner, wawancara serta observasi langsung dengan admin order desk dan pihak gudang serta pihak - pihak yang terkait dengan pengiriman barang. Sedangkan data sekunder yang digunakan dalam penelitian ini adalah literatur yang berhubungan dengan pengujian pengendalian, dokumentasi perusahaan, data jenis stok persediaan yang available digudang, alur proses pengiriman dan penerimaan barang dan datadata lain yang berhubungan dengan penelitian ini. Pada penelitian ada beberapa teknik untuk pengumpulan data yang berkaitan dengan penelitian ini.

Teknik pengumpulan data terdiri dari:

1. Interview (wawancara)

2. Observasi

3. Kuesioner

Adapun prosedur yang akan digunakan dalam penelitian ini adalah prosedur kuesioner, wawancara dan observasi dimana peneliti melakukan pengamatan langsung dilapangan terhadap pokok permasalahan yang dihadapi.

\section{Metode Analisis}

Metode yang digunakan untuk menganalisis penelitian ini adalah metode dengan pendekatan kualitatif analisis deskriptif yang didasarkan pada penggambaran yang mendukung analisa tersebut. Data yang diperoleh dari bagian logistik adalah List Persediaan Barang Jadi (Finish Good). Kemudian diolah dengan cara menganalisis, menerapkan dan menjelaskan sesuai dengan situasi yang sedang terjadi. Dari tahapan-tahapan tersebut dapat dilakukan pembahasan apakah pada bagian persediaan dan pergudangan sudah diterapkan 5 komponen pengendalian internal COSO (Committee of Sponsoring Organizations). 


\section{Pembahasan}

\section{Jenis Produk}

PT Denso Manufacturing Indonesia bergerak dibidang otomotif dan merupakan salah satu supplier industri otomotif seperti PT Astra Daihatsu Motor, PT Honda Prospect Motor, PT Toyota Motor Manufacturing, dan perusahaan otomotif lainnya. Salah satu produk-produk yang dihasilkan PT Denso Manufacturing Indonesia :

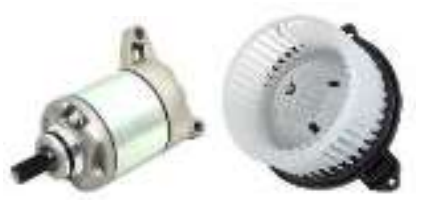

Motor Assy Blower

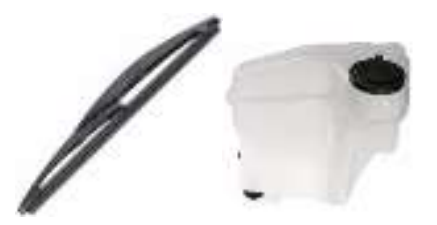

Rear Wiper Washer Tank

Gambar 1. Produk PT. Denso Manufacturing Indonesia

\section{Hasil Penelitian}

\section{Penerapan Pengendalian Internal Pada Persediaan Barang Jadi PT. Denso Manufacturing Indonesia.}

Penelitian yang dilakukan melalui kuesioner dan wawancara berdasarkan lima komponen pengendalian internal menurut COSO (Committee Of Supporting Organization Of the Treadway Comisson) kepada karyawan PT. Denso Manufacturing Indonesia. Berikut adalah hasil dari koesioner dengan mengambil sampel dari produksi, finished good, Deliverry.

Tanggapan hasil wawancara dan kuesioner yang telah dibagikan kurang lebih 20 lembar oleh masing-masing divisi menunjukan bahwa perusahaan telah memiliki lingkungan pengendalian yang baik. Proses pemesanan barang sudah terstruktur, selain itu, perusahaan memiliki struktur organisasi dan standar operasional prosedur yang jelas sehingga pengendalian dapat berjalan dengan baik. Namun masih terdapat kekurangan Seperti pergantian karyawan masuk dengan yang habis kontrak hanya berselang waktu 1 minggu.

Penilaian risiko atas persediaan yang dilakukan oleh manajemen PT. Denso Manufacturing Indonesia adalah penyajian informasi dikatakan wajar dan tepat waktu serta produk yang dihasilkan memiliki kualitas yang baik. Penilaian yang dilakukan yaitu dengan menjaga mutu barang yang disimpan dengan cara penentuan lokasi persediaan dan system penyimpanan yang sesuai dengan jenis dan karakter dari persediaan tersebut. Selain itu pemeriksaaan kondisi barang serta masa expired untuk material chemical dilakukan secara 
berkala dalam upaya menghindari barang dari kerusakan. Serta melakukan pengecekan terhadap jumlah fisik persediaan juga dilakukan secara berkala, dan membandingkan jumlah actual barang yang tersedia dengan jumlah barang yang ada pada system. Hal ini dapat memperkecil risiko atas penumpukan barang yang memungkinkan menyebabkan biaya tambahan, maupun kekurangan persediaan yang dapat menghambat proses produksi maupun proses distribusi, serta mengurangi kemungkinan terjadinya kecurangan atas persediaan. Namun masih terdapat sedikit kekurang Manajemen belum sepenuhnya mengidentifikasi risiko yang ada pada persediaan, sehingga masih terdapat beberapa temuan saat audit.

Aktivitas pengendalian adalah kebijakan dan prosedur yang membantu untuk memastikan bahwa arahan manajemen telah dilakukan dan diterapkan untuk mengatasi risiko. PT. Denso Manufacturing Indonesia memiliki deskripsi pekerjaan yang jelas, pemisahan tugas telah diterapkan dengan baik, memisahkan fungsi tiap-tiap divisi untuk mencegah terjadinya kecurangan dalam pelaporan. Dan transaksi telah didukung oleh dokumen serta catatan yang memadai.

Sistem informasi dan komunikasi yang dilakukan oleh PT. Denso Manufacturing Indonesia sudah cukup baik. Hal ini dapat dilihat dari penyusunan prosedur yang jelas di dalam perusahaan, termasuk di dalam prosedur pengawasan persediaan barang jadi, yang melibatkan fungsi terkait, dokumen dan catatan yang diperlukan serta laporan yang dihasilkan dan pencatatan kedalam catatan akuntansi harus didasarkan atas sumber yang di lampiri dengan dokumen pendukung yang lengkap yang di otorisasi oleh pihak yang berwenang. Namun masih terdapat beberapa hal yang menyebabkan kendali saat penyampaian informasi serta masih sering terjadi misscomunication antar lawan shift.

Pemantauan oleh PT. PT. Denso Manufacturing Indonesia atas segala kegiatan yang berhubungan dengan persediaan barang jadi dilakukan secara berkala. Dan dari pengawasan tersebut, manajemen dapat mengevaluasi kinerja dari setiap bagian yang berhubungan dengan persediaan barang jadi. Dari hasil evaluasi tersebut dapat diketahui apakah setiap kegiatan telah berjalan dengan baik serta sesuai dengan yang direncanakan, dan apakah terdapat kegiatan yang kurang efektif, sehingga diperlukan tindakan perbaikan. Dari hal tersebut maka akan muncul kebijakan baru sebagai upaya mengurangi hambatan dalam kegiatan operasional perusahaan menjadi semakin baik. Menurut penulis, upaya yang dilakukan oleh manajemen PT. Denso Manufacturing Indonesia sudah cukup baik. Hal ini dapat terlihat dari tingkat pengawasan dan evaluasi yang dilakukan terus menerus.

\section{Tindakan Penyimpangan Dalam Pengendalian Internal Pada Persediaan Barang Jadi PT. Denso Manufacturing Indonesia}

Prosedur pengendalian internal atas persediaan barang dagang dan pergudangan pada PT. Denso Manufacturing Indonesia sudah berjalan dengan baik dan dijalankan sesuai dengan standar operasional prosedur (SOP), dalam hal ini tidak ditemukan nya penyimpangan dalam pengendalian internal yang sudah dijalankan perusahaan. Hanya saja masih terdapat beberapa kekurangan dalam sistem pengendalian yang sudah diterapkan oleh PT. Denso Manufacturing Indonesia.

\section{Kesimpulan}

Berdasarkan hasil analisa dan pembahasan diatas, dapat diambil kesimpulan pengendalian internal atas persediaan yang diterapkan pada PT. Denso Manufacturing Indonesia sebagai berikut : 
1. Secara keseluruhan sistempengendalian internal Pada persediaan Barang Jadi PT. Denso manufacturing Indonesia berjalan secara baik dan efektif, Namun masih terdapat beberapa kekurangan seperti pergantian karyawan yang telah habis kontrak dengan karyawan baru hanya berselang waktu 1 minggu, pergantian tersebut menyebabkan karyawan kurang pelatihan saat akan bekerja ditempat yang akan dia gantikan, pihak manajemen belum sepenuhnya mengindetifikasi risiko yang ada pada persediaan. Serta komunikasi yang terhambat akibat kurangnya fasilitas telepon yang diperbolehkan di area produksi, logistic dan masih sering terdapat misscomunication antar lawan shift.

2. Tidak ditemukan penyimpangan yang terjadi pada PT. Denso Manufacturing Indonesia karena perusahaan telah memiliki struktur organisasi yang jelas dalam pemisahan fungsi dan tugas setiap bagian, hanya saja masih terdapat kekurangan saja dalam pengendalian internalnya.

\section{Implikasi Manajerial}

Impilikasi manajerial dari pembahasan dan hasil analisa data dalam penelitian penerapan pengendalian internal persediaan barang jadi pada PT. Denso Manufacturing Indonesia ini diharapkan dapat bermanfaat bagi pihak - pihak yang berkepentingan oleh perusahaan adalah sebagai berikut :

1. Perekrutan karyawan baru dilakukan sebulan sebelum karyawan habis kontrak/ resign dari perusahaan sehingga memberikan waktu yang cukup untuk karyawan baru belajar dari karyawan lama. Identifikasi yang dilakukan manajemen dilaksanakan rutin $2 \mathrm{x}$ dalam seminggu untuk menhindari adanya temuan saat audit dilaksanakan. Fasilias telepon di area produksi dan logistic ditambah, sehingga memudahkan karyawan dalam menyampaikan informasi dan mempermudah jalur komunikasi. Selain informasi dilakukan secara lisan, lebih baik informasi tersebut juga ditulis kedalam buku catatan pertukaran informasi antar shift, sehingga tidak terjadi misscomunication.

2. Aktifkan karyawan dalam melakukan kaizen atau saran perbaikan untuk mengindentifikasi risiko yang mungkin terjadi agar kekurangan-kekurangan yang terdapat dalam pengendalian bisa dapat dideteksi dan tidak merugikan perusahan. Berikan karyawan rewards yang sesui dengan hasil perbaikan mereka agar mereka semangat dalam melakukannya.

\section{Daftar Pustaka}

Hery. (2015). Pengantar Akuntansi. Jakarta : Gramedia Widiasarana Indonesia.

Hery. (2017). Auditing dan Asurans : Pemeriksaan Akuntansi Berbasis Standar Audit Internasional. Jakarta : Gramedia Widiasarana Indonesia.

Mulyadi. (2014). Sistem Akuntansi. Jakarta : Salemba Empat.

Eddy Herjanto. (2010), Manajemen Operasi. Gramedia : Jakarta.

Kartikahadi. (2012). Akuntansi Keuangan Berdasarkan SAK berbasis IFRS. Jakarta : Salemba Empat.

Heizer, Jay \&Render Barry. (2015).Manajemen Operasi: Manajemen Keberlangsungan dan Rantai Pasokan, edisi 11. Jakarta : Salemba Empat 
INOBIS: Jurnal Inovasi Bisnis dan Manajemen Indonesia

Volume 03, Nomor 04, September 2020

Matdio Siahaan, Ahmad Torikul Muhidin

Yesi, Kardinal. (2010). Analisis Perencanaan dan Pengendalian Persediaan Barang Jadi pada CV. Tedmond Fibre Glass. Palembang : STIE MDP.

Alex Tarukdatu Naibaho. (2013). Analisa Pengendalian Internal Persediaan Bahan Baku Terhadap Efektifitas Pengelolaan Persediaan Bahan Baku.

Nova Sumual, Lintje Kalangi. (2014). Evaluasi Pengendalian Intern untuk Siklus Persediaan Barang Dagangan pada SPBU Kolongan. Manado : Universitas Sam Ratulangi Manad 